\title{
The Black-Scholes Model Guideline For Options Course As Taught At Notre Dame University - Lebanon
}

Viviane Y. Naïmy, (Email: vnaimy@aud.edu), American University, UAE

\begin{abstract}
This paper presents the methodology used for Notre Dame University's finance students to explain and explore the Black-Scholes model without going through the complexity of mathematics to model random movements or through stochastic calculus. I will name and develop the steps that I follow in order to allow students to properly use the Black-Scholes model and to understand the relationship of the model's inputs to the option price while monitoring the risk via delta and gamma hedging.
\end{abstract}

\section{INTRODUCTION}

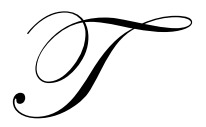

he knowledge required to develop the Black-Scholes model came from mathematics and physics. The roots of the model's formula go back to Robert Brown in the 1820's when he observed the motion pollen suspended in water and noticed that movements followed no distinct pattern. This phenomenon was known as the Brownian motion and was used by Albert Einstein to explain movements of molecules. In 1951, Kiyoshi Itô developed the Itô's Lemma which constituted a good introduction to find an option's price. BLACKSCHOLES model has been one of the most significant developments in the history of the pricing of financial instruments.

Beyond stochastic calculus and differential equations used to price an option, this paper elucidates the financial interpretation of the Black-Scholes model with respect to its mathematical background without reducing and simplifying the structure of the model. I will outline the methodology used to explain the Black-Scholes model to Notre Dame University's ${ }^{1}$ finance students. The model's variables and their impact on the option price are also explored in details. Finally, I will summarize the steps that I follow for illustrating the management of the risk of options.

\section{SESSION 1: BLACK-SCHOLES MODEL AS THE LIMIT OF THE BINOMINAL MODEL}

\section{Step One:}

First, I try to remind the students about few concepts such as logarithms, exponentials, limits, normal and lognormal distributions, standard normal probabilities, etc. Then, I compare the binominal model and the notion of a dynamic risk-free hedge in which no arbitrage opportunities are available with the Black-Scholes model and I remind students that the binomial model is in discrete time, i.e., as we decrease the length of each time step, it converges to continuous time.

\footnotetext{
${ }^{1}$ Notre Dame University, Louaize Lebanon, Faculty of Business Administration \& Economics, Department of Accounting, Finance, and Economics. The course title is Options \& Futures (BAF 450), it's a senior course for finance students.
} 


\section{Step Two:}

I display the Assumptions of the Model where:

1. stock prices behave randomly and evolve according to a lognormal distribution,

2. the risk-free rate and volatility of the log return on the stock are constant throughout the option's life,

3. there are no taxes or transaction costs,

4. the stock pays no dividends, and

5. the options are European.

\section{Step Three:}

Step three is devoted to identify the variables of the model:

$\mathrm{C}=\mathrm{S}_{0} \mathrm{~N}\left(\mathrm{~d}_{1}\right)-\mathrm{Xe}^{-\mathrm{r}_{\mathrm{c}} \mathrm{T}} \mathrm{N}\left(\mathrm{d}_{2}\right)$

where

$\mathrm{d}_{1}=\frac{\ln \left(\mathrm{S}_{0} / \mathrm{X}\right)+\left(\mathrm{r}_{\mathrm{c}}+\sigma^{2} / 2\right) \mathrm{T}}{\sigma \sqrt{\mathrm{T}}}$

$\mathrm{d}_{2}=\mathrm{d}_{1}-\sigma \sqrt{\mathrm{T}}$

where

$\mathrm{N}(\mathrm{d} 1), \mathrm{N}(\mathrm{d} 2)=$ cumulative normal probability

$\mathrm{s}=$ annualized standard deviation (volatility) of the continuously compounded return on the stock

$\mathrm{r}_{\mathrm{c}}=$ continuously compounded risk-free rate

$\mathrm{N}(\mathrm{d} 1)$ and $\mathrm{N}(\mathrm{d} 2)$ are determined using the normal probability table (z statistic) for $\mathrm{d} 1$ and $\mathrm{d} 2$.

\section{SESSION 2: INTERPRETING THE B-S MODEL}

I insist during this session on the explanation and the interpretation of the Black-Scholes model. My objective is not to let students memorize the formula or simply plug in the numbers into the specialized software to obtain the theoretical value of a given option, rather I make sure to elucidate the foundations and the justification of each term of the formula.

I refer to the concept of risk neutrality, risk neutral probability, and its role in pricing options before I demonstrate the "financial" aspect of the model not the mathematical one.

Consequently, it becomes obvious for the students that the option price, with respect to the above mentioned concept, is the discounted expected payoff, $\operatorname{Max}\left(0, \mathrm{~S}_{\mathrm{T}}-\mathrm{X}\right)$. Therefore, we need the expected value of $\mathrm{S}_{\mathrm{T}}-\mathrm{X}$ for those cases where only $\mathrm{S}_{\mathrm{T}}>\mathrm{X}$.

We know that $\mathrm{C}=\mathrm{S}_{0} \mathrm{~N}\left(\mathrm{~d}_{1}\right)-\mathrm{Xe}^{-\mathrm{r}_{\mathrm{c}} \mathrm{T}} \mathrm{N}\left(\mathrm{d}_{2}\right)$

\section{Step One:}

Multiplying this equation by $e^{r_{c} T}$, the first term on the right-hand side becomes equal to $S_{0} N\left(d_{1}\right) e^{r_{c} T}$, which is the expected value of the stock price at expiration ${ }^{2}$ times the probability that the stock price exceeds the exercise

\footnotetext{
${ }^{2}$ Since our starting point is with $\mathrm{S}_{0}$, we are obliged to follow our objective, which is to calculate the expected payoff at expiration $\left(\mathrm{S}_{\mathrm{T}}\right)$ and then to discount it, that's why we use the continuous future factor $\mathrm{e}^{-\mathrm{r}_{\mathrm{c}} \mathrm{T}}$.
} 
price at expiration ${ }^{3}$. As for the second term on the right-hand side, it becomes equal to $-\mathrm{XN}\left(\mathrm{d}_{2}\right)$ which represents the expected value of the payment of the exercise price at expiration ${ }^{4}$. Thus, equation (1) becomes:

$S_{0} N\left(d_{1}\right) e^{r_{c} T}-X N\left(d_{2}\right)$

Step Two:

Discounting equation (2) at the continuously compounded risk free rate, $e^{-r_{c} T}$, gives:

$S_{0} N\left(d_{1}\right) e^{r_{c} T} * e^{-r_{c} T}-X N\left(d_{2}\right) * e^{-r_{c} T}=S_{0} N\left(d_{1}\right)-X e^{-r_{c} T} N\left(d_{2}\right)=C$

After this interpretation, I let the students analyze the characteristics of the Black-Scholes formula when:

1. $\mathrm{T}=0$

2. $\mathrm{S} 0=0$

3. $\sigma=0$

4. $\mathrm{X}=0$

5. $\mathrm{r}_{\mathrm{c}}=0$

\section{SESSION 3-4: THE VARIABLES IN THE FORMULA}

These two sessions are devoted to explaining the impact of each variable in the formula on the option's price. I deal with the following fields as follows:

\section{The Stock Price:}

I explore here three dimensions:

1. The delta ${ }^{5}$ effect, which is given by $\mathrm{N}(\mathrm{d} 1)$, where delta ranges from zero to one. Delta changes throughout the option's life.

2. The delta hedging/delta neutral ${ }^{6}$, where the number of shares held per option sold is the delta, $N(\mathrm{~d} 1)$. As the stock goes up/down by $\$ 1$, the option goes up/down by $\mathrm{N}(\mathrm{d} 1)$. By holding $\mathrm{N}(\mathrm{d} 1)$ shares per call, the effects offset. The position must be adjusted as the delta changes.

3. The Gamma hedging: Delta hedging works only for small stock price changes. For larger changes, the delta does not accurately reflect the option price change. This risk is captured by the gamma ${ }^{7}$. I don't insist on Gamma formula by itself, but I make sure to provide students with concrete examples showing how gamma captures most of the change in delta ${ }^{8}$.

\section{The Exercise Price}

This is useful only for comparing options differing only by a small change in the exercise price. In most options the exercise price does not change.

\footnotetext{
${ }^{3}$ It's worth mentioning that $\mathrm{N}(\mathrm{d} 1)$ is not that probability. It is just a component of the entire expression.

${ }^{4} \mathrm{~N}(\mathrm{~d} 2)$ is in this case the probability for risk neutral investors that $\mathrm{X}$ will be paid at expiration.

${ }^{5}$ Which measures the change in call price over the change in stock price for a very small change in the stock price.

${ }^{6}$ Holding shares of stock and selling calls to maintain a risk-free position.

${ }^{7}$ Call Gamma $=\frac{\mathrm{e}^{-\mathrm{d}_{1}^{2} / 2}}{\mathrm{~S}_{0} \sigma \sqrt{2 \pi \mathrm{T}}}$

${ }^{8}$ The delta is predicted to change from initial delta $+($ the change in the stock price) times Gamma $=$ new delta at the new stock price.
} 


\section{The Risk-Free Rate9}

The effect is called rho ${ }^{10}$. Again, I concentrate on the use of rho rather than on its formula. If the risk-free rate changes, the rho estimates that the call price will go to $(\Delta \text { risk-free rate })^{*}$ rho $=$ The actual change in $\mathrm{C}$.

\section{The Volatility}

I give a particular attention to this variable since it is the most critical one in the Black-Scholes model and since the option price is very sensitive to the standard deviation and it is the only unobservable variable. This effect is known as vega ${ }^{11}$. Thus if volatility changes, the call price is estimated to change by Vega*( $\Delta$ volatility).

\section{The Time to Expiration ${ }^{12}$}

This effect is known as theta ${ }^{13}$. If for example one week elapsed, the call price would be expected to change to $(\Delta$ time to expiration $)($ theta $)=$ The actual call price changes.

In order to help and assist my students in calculating all the above mentioned variables (delta, gamma, vega, rho, and theta, for calls and puts) I provide them with a specialized excel spreadsheet written by Don Chance ${ }^{14}$ and I make sure to succeed the software demonstration during the class session. Students insert values in highlighted cells. Risk-free rate, standard deviation and yield can be entered as decimal or percentage. They can select the form (discrete or continuous) for risk-free rate. Black-Scholes values automatically recalculate. They click on "Run Binomial Option Pricing Model" button to recalculate binomial values. Input cells have double borders. Output cells have single borders. Up to 1,000 time steps can be used in the binomial model. They can also input a continuous dividend yield or up to 50 discrete dividends. The below table illustrates the required inputs and the corresponding outputs related to the Binominal and to the Black-Scholes Models.

\section{SESSION 5-6: MANANGING THE RISK OF OPTIONS}

These sessions are very important for students. Here I explain how option dealers hedge the risk of option positions they take. I give the students a concrete example about a stock daily price movement covering a period of 35 days. All the Black-Scholes variables are also given for the option price calculation. I simulate the daily stock prices for 35 days, at which time the call expires. I demonstrate using daily hedge simulation that large price changes, combined with an inability to trade continuously, result in imperfections in the delta hedge. To deal with this problem, I must gamma hedge, i.e., reduce the gamma to zero. I can do this only by adding another option.

\footnotetext{
${ }^{9}$ Where $\mathrm{rc}=\ln (1+$ discrete risk-free rate $)$

${ }^{10}$ Call Rho $=\mathrm{TXe}^{-\mathrm{r}_{\mathrm{c}} \mathrm{T}} \mathrm{N}\left(\mathrm{d}_{2}\right)$

${ }^{11}$ Call vega $=\frac{\mathrm{S}_{0} \sqrt{\mathrm{Te}} \mathrm{e}^{2} / 2}{\sqrt{2 \pi}}$

${ }^{12}$ Calculated as (days to expiration)/365

${ }^{13}$ Call theta $=-\frac{\mathrm{S}_{0} \sigma e^{-\mathrm{d}_{1}^{2} / 2}}{2 \sqrt{2 \pi \mathrm{T}}}-\mathrm{r}_{\mathrm{c}} \mathrm{Xe}^{-\mathrm{r}_{\mathrm{c}} \mathrm{T}} \mathrm{N}\left(\mathrm{d}_{2}\right)$

${ }^{14}$ For use with An Introduction to Derivatives and Risk Management, 6th ed. (Mason, Ohio: South-Western Thomson, Inc., 2004)
} 

condition is:

The symbols $\Delta 1, \Delta 2, \Gamma 1$ and $\Gamma 2$ are used. We use $\mathrm{h}_{\mathrm{S}}$ shares of stock and $\mathrm{h}_{\mathrm{C}}$ of calls. The delta hedge

$\mathrm{h}_{\mathrm{S}}(1)-1,000 \Delta 1+\mathrm{h}_{\mathrm{C}} \Delta 2=0$

The gamma hedge condition is:

$-1,000 \Gamma 1+\mathrm{h}_{\mathrm{C}} \Gamma 2=0$

We can solve equation (8) and get $\mathrm{h}_{\mathrm{C}}$ and then substitute back into equation (7) to get $\mathrm{h}_{\mathrm{s}}$. Solving for $\mathrm{hC}$ and hS, we obtain:

$\mathrm{h}_{\mathrm{C}}=1,000(\Gamma 1 / \Gamma 2)$

$\mathrm{h}_{\mathrm{S}}=1,000(\Delta 1-(\Gamma 1 / \Gamma 2) \Delta 2)$

I start a daily simulation until I reach one conclusion: gamma hedging reduces the difference of portfolios, thus, we are much closer than when we only use delta hedging.

Black-Scholes and Binomial Option Pricing

Inputs:

Asset price $\left(\mathrm{S}_{0}\right)$

Exercise price (X)

Time to expiration $(\mathrm{T})$

Standard deviation $(\sigma)$

Risk-free rate $\left(r\right.$ or $\left.r_{c}\right)$

Dividends: continuous yield

$\left(\delta_{\mathrm{c}}\right)$ or discrete dividends

below:
125.9375

125

0.0959

$83.00 \%$

$4.46 \%$

$0.00 \%$

\begin{tabular}{|l|}
\hline discrete \\
\hline continuous \\
\hline
\end{tabular}

Price

Delta $(\Delta)$

Gamma (广́)

Theta $(\theta)$

Vega
Black-Scholes Model

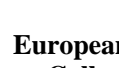

Call

13.5512

0.5692

0.0121

$-68.9109$

15.3236
European

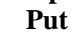

12.0803

$-0.4308$

0.0121

$-63.3597$

15.3236

\begin{tabular}{|c|c|}
\hline & $\begin{array}{c}\text { Run Binomial } \\
\text { Model }\end{array}$ \\
\hline \multicolumn{2}{|c|}{ Binomial Model } \\
\hline Steps: & 100 \\
\hline $\begin{array}{l}\text { European } \\
\text { Call }\end{array}$ & $\begin{array}{c}\text { European } \\
\text { Put }\end{array}$ \\
\hline 13.5507 & 12.0799 \\
\hline 0.5700 & -0.4300 \\
\hline 0.0121 & 0.0121 \\
\hline $\begin{array}{l}-68.9148 \\
-68.9148\end{array}$ & -63.3647 \\
\hline
\end{tabular}

In Lieu of a continuously compounded yield, place below up to fifty discrete dividends and he time I years o each ex-dividend date. Leave all unused cells blank. Se the yield to zero, all discrete dividends are disregarded

\begin{tabular}{lllllcc} 
& & & & \multicolumn{2}{c}{ Call } & Put \\
Dividend \# & Dividend & Time to & Present & Price & 13.5507 & 12.1132 \\
1 & & ex date & Value & & & \\
2 & 0.0000 & 0.0000 & 0.0000 & Delta $(\square)$ & 0.5700 & -0.4317 \\
& 0.0000 & 0.0000 & 0.0000 & Gamma $(\square)$ & 0.0121 & 0.0122 \\
& & & & Theta $(\square)$ & -68.9148 & -63.7697
\end{tabular}

\section{CONCLUSION}

I have been successfully using this teaching approach in the classroom. My students have access to specialized software for options pricing. I avoid the descriptive teaching attitude and at the same time I don't allow students to get lost in the complexity of differential equations. In the contrary, I keep track with mathematics by using this latter to serve the purpose of options pricing model. Consequently, students have equilibrium between the theory of the Black-Scholes model and the practical side of this formula. I have effectively transformed the students' fear from the Black-Scholes model into a controllable and fruitful model to be used by them in real life. 


\section{BIBLIOGRAPHY}

1. Amihud, Y. and Mendelson, H. (1986), Asset Pricing and Bid-Ask Spread, Journal of Financial Economics, Vol. 17, No.2, December, pp. 223-249.

2. Chance, Don M. An Introduction to Derivatives \& Risk Management, $6^{\text {th }}$ edition: Thomson, South-Western (2004).

3. Balck, F. (1989). How We Came Up with the Option Formula, Journal of Portfolio Management 15 (winter). P 4-8.

4. Balck, F. and Scholes, M. (1973). The Pricing of Options and Corporate Liabilities. Journal of Political Economy 81. p. 637-659

5. Hull, John C. Options, Futures, and Other Derivatives, $5^{\text {th }}$ edition, Prentice Hall, 2003.

6. Hull, John C. Fundamentals of Futures and Options Markets, $4^{\text {th }}$ edition, Prentice Hall, 2002

7. Merton, C. (1973). Theory of Call Option Pricing. Bell Journal of Economics and Management Science 4. p 141-183.

8. Naïmy, V. (2005), Overall Lebanese Banks' Performance: A Risk-Return Framework. The International Business And Economics Research Journal, Volume 4, Number 1, January, p. 1-10.

9. Numa Option Calculator website: www.numa.com/derivs/ref/calculat/option/calc-opa.htm

\section{NOTES}

